https://doi.org/10.17816/MAJ191S121-22

\title{
BIOCHEMICAL ALTERATIONS IN ONCOPEDIATRIC PATIENTS DURING SEPSIS
}

\author{
E.G. Golovnya, A.V. Lebedeva, T.Yu. Kharitidi, A.V. Sotnikov \\ N.N. Blokhin National Medical Research Center of Oncology, Moscow, Russia
}

\section{БИОХИМИЧЕСКИЕ ИЗМЕНЕНИЯ У ОНКОПЕДИАТРИЧЕСКИХ ПАЦИЕНТОВ ПРИ СЕПСИСЕ}

\author{
Е.Г. Головня, А.В. Лебедева, Т.Ю. Харитиди, А.В. Сотников \\ ФГБУ «НМИЦ онкологии им. Н.Н. Блохина» Минздрава России, Москва
}

In the current study, biochemical abnormalities occurring in the body of children with cancer in sepsis, as well as their relationship with the new marker of sepsis and phagocytosis by presepsin, are considered. A survey enrolled 112 children who were treated at the N.N. Blokhin National Medical Research Center of Oncology. Differences in medians of a number of biochemical parameters in groups of patients who survived and died of sepsis were revealed.

Keywords: sepsis; children; multiorgan failure; oncology; presepsin; routine biochemical parameters.

Рассмотрены биохимические нарушения, возникающие в организме детей с онкологическими заболеваниями при сепсисе, а также их взаимосвязь с новым маркером сепсиса и фагоцитоза пресепсином. Проведено обследование 112 пациентов детского возраста, проходивших лечение в Национальном медицинском исследовательском центре онкологии им. Н.Н. Блохина. Выявлены различия медиан ряда биохимических показателей в группах выживших и умерших от сепсиса пациентов.

Ключевые слова: сепсис; дети; полиорганная недостаточность; онкология; пресепсин; рутинные биохимические показатели.

Introduction. Sepsis remains one of the most pressing problems in modern medicine due to the growth of its prevalence and consistently high mortality. Childhood cancer patients receiving immunosuppressive therapy represent a particular risk group for the development of sepsis. In recent years, a new marker, presepsin, has been proposed for the early diagnosis of sepsis, which is a soluble fragment of the CD14 receptor.

Material and methods. The study enrolled 112 patients with cancer up to 18 years old who were diagnosed with sepsis based on clinical symptoms. The patients were divided into 3 groups: survivors $(n=85)$, non-survivors $(n=17)$, control $(n=13)$. The analysis included indicators: the level of presepsin and general blood biochemical parameters. Presepsin was determined on a Pathfast immuno-chemiluminescent analyzer, biochemical parameters were measured on a Pentra 400 analyzer.

Results and discussion. Comparison of medians showed significant differences in the groups

Введение. Сепсис остается одной из самых актуальных проблем в современной медицине ввиду роста ее распространенности и стабильно высокой летальности. Онкологические больные детского возраста, получающие иммуносупрессивную терапию, представляют особую группу риска развития сепсиса. В последние годы был предложен новый маркер для ранней диагностики сепсиса - пресепсин, представляющий собой растворимый фрагмент рецептора CD14. of survivors and non-survivors in terms of presep$\sin (69.8$ vs $1438 \mathrm{pg} / \mathrm{ml}, p<0.0001)$. Comparison with reference values showed that the level of presepsin in the group of the dead was increased 13 times compared with the normal values, 4.7 times compared with the group of survivors and 24 times compared with the control group. The median of total bilirubin in the group of nonsurvivors was increased by 3.65 times, and the direct one - by 13.8 times compared with normal values. In the group of survivors, the median does not exceed reference range. In the group of survivors, significant correlations of presepsin with total bilirubin and GGT were found $(r=0.34$ and $r=0.4, p<0.01$ ). In the group of non-survivors, the identified correlations between presepsin and total and direct bilirubin, iron and urea $(r=0.77$, $r=0.79, \quad r=0.59, \quad r=0.64, \quad p<0.01) \quad$ confirm the assumption increased erythrocyte breakdown in sepsis and aggravation of multiple organ failure.

Материалы и методы исследования. В исследование было включено 112 пациентов с онкологическими заболеваниями до 18 лет, у которых был диагностирован сепсис на основании клинических симптомов. Пациенты были разделены на 3 группы: выжившие $(n=85)$, умершие $(n=17)$, контроль $(n=13)$. В анализ включали показатели: уровень пресепсина и общие биохимические показатели крови. Пресепсин определяли на иммунохемилюми- 
нисцентном анализаторе Pathfast, биохимические показатели - на анализаторе Pentra 400.

Результаты и их обсуждение. Сравнение медиан показало достоверные различия в группах выживших и умерших по уровню пресепсина (69,8 vs 1438 пг/мл, $p<0,0001)$. Сравнение с референсными значениями показало, что уровень пресепсина в группе умерших повышен в 13 раз по сравнению с нормой, в 4,7 раза - по сравнению с группой выживших и в 24 раза по сравнению с группой контроля. Медиана общего билирубина в группе умерших повыше- на в 3,65 раза, а прямого - в 13,8 раз относительно нормы. В группе выживших медиана не превышает норму. В группе выживших выявлены значимые корреляции пресепсина с общим билирубином и ГГТ ( $r=0,34$ и $r=0,4, p<0,01)$. В группе умерших выявленные корреляционные зависимости между пресепсином и общим и прямым билирубином, железом и мочевиной $(r=0,77, r=0,79, \quad r=0,59, r=0,64, p<0,01)$ подтверждают предположение об усиленном распаде эритроцитов при сепсисе и усугублении полиорганной недостаточности. 